\title{
Consensus report: E. coli 0104:H4 (HUSEC041) and the potential threat to European water supplies
}

\author{
Martin Exner ${ }^{\mathrm{a}, *}$, Philippe Hartemann ${ }^{\mathrm{b}}$, Paul R. Hunter ${ }^{\mathrm{c}}$, Yves Levi ${ }^{\mathrm{d}}$, Jean-Francois Loret $^{\mathrm{e}}$, \\ Werner Mathys $^{\mathrm{f}}$, Daniel Villesot ${ }^{\mathrm{e}}$, Michael Wilhelm ${ }^{\mathrm{g}}$ \\ a Institute for Hygiene and Public Health, University of Bonn, Germany \\ b Département Environnement et Santé Publique, Faculté de Médecine, Nancy Université, France \\ c The Norwich School of Medicine, University of East Anglia, Norwich, United Kingdom \\ d Paris University, France \\ e Lyonnaise des Eaux, Paris, France \\ ${ }^{\mathrm{f}}$ Institute for Hygiene, University of Münster, Germany \\ g Department of Hygiene, Social and Environmental Medicine, Ruhr University Bochum, Bochum, Germany
}

\section{A R T I C L E I N F O}

\section{Article history:}

Accepted 9 August 2011

\section{Keywords:}

E. coli 0104:H4 (HUSEC041)

Water suppliers

Small water systems

Processing of food

\begin{abstract}
A B S T R A C T
Among the 3rd Seminar for PhD students working on Water and Health which was held in Cannes on 27-29 June 2011, experts from a number of universities and research institutes took the opportunity to discuss the emergence of Escherichia coli 0104:H4 in Europe. Especially, possible threats for European water suppliers were considered. The consensus is summarized in this report. The main conclusion was that E. coli $0104: \mathrm{H} 4$ would not pose a substantial risk to well managed water supplies, especially where regular monitoring of indicator E. coli is negative. However, this may not apply for small and very small water systems which are quite common in Europe. New strategies like the Water Safety Plan approach are needed to protect also small scale drinking water systems and private wells in Europe. Water used in the processing of foods likely to be eaten raw, especially sprouts, should be of drinking water quality.
\end{abstract}

\section{Consensus report}

The 3rd Seminar for PhD students working on Water and Health was held in Cannes on 27-29 June 2011. This seminar was attended by $\mathrm{PhD}$ students and also senior professors (in alphabetic order: Prof. Dr. M. Exner, Bonn, Prof. Dr. P. Hartemann, Nancy, Prof. P.R. Hunter, Prof. Dr. Y. Levi, Paris, Dr. J.F. Loret, Paris, Dr. D. Villessot, Paris, and Prof. Dr. M. Wilhelm, Bochum) with special expertise in water and health from a number of universities and research institutes. At this conference the opportunity was taken to discuss the emergence of Escherichia coli 0104:H4 in Europe and to consider what if any additional threats this may present for drinking water supplies in Europe which was also consented with Prof. Dr. W. Mathys, Münster. The following summarises the main conclusions.

1. At present it is not possible to predict how the epidemiology of this re-emergent, exceptionally virulent strain may develop (Frank et al., 2011). It is plausible that the strain may not become established but disappears. On the other hand it is also plausible that the strain may become established in a human

\footnotetext{
* Corresponding author.

E-mail address: martin.exner@ukb.uni-bonn.de (M. Exner).
}

or perhaps in a still unknown animal reservoir and continues to pose a threat to public health for many years.

2. It is also not possible to state with certainty whether it will retain its apparent increased virulence.

3. To our knowledge there is no indication that this re-emergent strain has been transmitted by drinking water.

4. However, other enterohemorrhagic/Shiga toxin producing (STEC) strains of E. coli such as E. coli O157:H7 have caused well described drinking water outbreaks such as the Walkerton outbreak in Canada that was associated with more than 2000 cases and 7 deaths. Most drinking water associated outbreaks were associated with deficiencies in water treatment and/or disinfection especially in small water scale utilities and after heavy rainfall (Ackman et al., 1997; Bruneau et al., 2004; Friedman et al., 1999; Harrison and Kinra, 2004; Holme, 2003; Jones and Roworth, 1996; Olsen et al., 2002; Paunio et al., 1999; Wang et al., 2004). To the best of our knowledge, no outbreaks have been associated with well managed water systems. The exposure route drinking water is favoured by the very low infectious dose of E. coli $0157: \mathrm{H7}$.

5. Until now it must be assumed that the emerging pathogen E. coli $0104: \mathrm{H} 4$ seems to have similar properties as E. coli 0157:H7 such as low infectious dose, broad temperature range, high resistance against acids, broad antibiotic resistance (ESBL), biofilm production which are possible risk factors for 
transmission by drinking water or other waters (Askar et al., 2011; Scheutz et al., 2011). Other environmental characteristics for tenacity are under investigation.

6. At the time of writing there is no evidence of an animal host for E. coli 0104:H4 and infection seems, for the time being at least to be restricted to human. This is unlike the case for $E$. coli 0157:H7 which has as its main reservoir domestic livestock in which it is often asymptomatic. It is not yet clear whether $E$. coli 0104:H4 has the potential for colonising animals, or developing a reservoir in livestock. If the strain does widely colonise livestock or other animals then the risks associated with the contamination of the environment and water reservoirs will increase.

7. The finding of E. coli $\mathrm{O} 104: \mathrm{H} 4$ in a creek influenced by a sewage utility in the German Federal State of Hesse is an indication that the emerging strain could begin to be distributed in the environment by the faecal route, though we are aware that subsequent samples taken from the creek were negative.

8. It seems reasonable to us that should E. coli 0104:H4 become established in humans or animals in Europe then, on account of its increased virulence, it will pose an additional risk to some drinking water supplies over and above that posed by established pathogens.

9. Given the propensity for E. coli O157:H7 to cause waterborne outbreaks primarily in small and very small inadequately managed drinking water systems it is likely that E. coli 0104:H4 would also be of primary concern in such systems.

10. Similarly it is unlikely that E. coli $0104: \mathrm{H} 4$ would pose a substantial risk to well managed water supplies, especially where regular monitoring of indicator $E$. coli is negative.

11. Small and very small water systems are common in Europe. For example, in Germany up to 20\% (about 16 million people) have drinking water distributed by small scale water utilities and private wells (WHO, 2011). In the Federal State of Baden-Württemberg, as an example, 523 selected samples from the approximately 13,500 private wells were analysed in 2007; non-compliance rates for E. coli and total coliforms were at $18 \%$ and $43 \%$, respectively. Non-compliance rates for small public water supplies serving fewer than 5000 people were at $2 \%$ and $5 \%$ for $E$. coli and total coliforms, respectively (cited from WHO, 2011). These figures are probably not specific to Germany, since in a survey carried out in 2009, one third of all small water supplies (serving from 50 to 5000 citizens) of European member states did not comply with the requirements of the Drinking Water Directive (Falkenberg, 2011).

12. In accordance with the proposal of the WHO Europe new strategies like the Water Safety Plan (WSP) approach are needed to protect also small scale drinking water systems and private wells in Europe. The emergence of a new bacterial strain with enhanced virulence makes this proposal even more urgent (WHO, 2011).

13. Where E. coli is detected in drinking water samples the owners of such supplies need to be strongly advised to disinfect or boil or treat by point of use filtration system any water prior to consumption as an acute reaction. Independent of the acute risk management strategies there is also an urgent need for a detailed risk evaluation of the quality of the drinking water system based on the WHO Water Safety Plan Concept.

14 . We strongly recommend that sampling methods for E. coli 0104:H4 in water be harmonised and laboratory proficiency tests performed as soon as possible.

15. International Guidelines for irrigating water quality should be re-evaluated. Water for irrigation for raw food vegetables and fruits should not be taken from creeks directly influenced by sewage.

16. Water used in the processing of foods likely to be eaten raw, especially sprouts, should be of drinking water quality. If such water is taken from a private supply then that supply should be subject to a risk assessment and regular microbiological monitoring.

\section{References}

Ackman, D., Marks, S., Mack, P., Caldwell, M., Root, T., Birkhead, G., 1997. Swimmingassociated haemorrhagic colitis due to Escherichia coli 0157:H7 infection: evidence of prolonged contamination of a fresh water lake. Epidemiol. Infect. 119, 1-8.

Askar, M., Faber, M., Frank, C., Bernard, H., Gilsdorf, A., Fruth, A., Prager, R., Hohle, M., Suess, T., Wadl, M., Krause, G., Stark, K., Werber, D., 2011. Update on the ongoing outbreak of haemolytic uraemic syndrome due to Shiga toxin-producing Escherichia coli (STEC) serotype 0104, Germany, May 2011. Euro Surveill. June $2,16(22)$.

Bruneau, A., Rodrigue, H., Ismael, J., Dion, R., Allard, R., 2004. Outbreak of E. coli 0157:H7 associated with bathing at a public beach in the Montreal-Centre region. Can. Commun. Dis. Rep. 30, 133-136.

Falkenberg, K., 2011. Drinking Water Directive, future implementation efforts. European Commission, Directorate-General Environment; Brussels, 14. April, 2011 COM(2011)208 final.

Frank, C., Werber, D., Cramer, J.P., Askar, M., Faber, M., Heiden, M.A., Bernard, H., Fruth, A., Prager, R., Spode, A., Wadl, M., Zoufaly, A., Jordan, S., Stark, K., Krause, G., the HUS Investigation Team, 2011. Epidemic profile of Shiga-toxin-producing Escherichia coli 0104:H4 outbreak in Germany - preliminary report. N. Engl. J. Med., doi:10.1056/NEJMoa1106483.

Friedman, M.S., Roels, T., Koehler, J.E., Feldman, L., Bibb, W.F., Blake, P., 1999. Escherichia coli 0157:H7 outbreak associated with an improperly chlorinated swimming pool. Clin. Infect. Dis. 29, 298-303.

Holme, R., 2003. Drinking water contamination in Walkerton, Ontario: positive resolutions from a tragic event. Water Sci. Technol. 47, 1-6.

Harrison, S., Kinra, S., 2004. Outbreak of Escherichia coli 0157 associated with a busy bathing beach. Commun. Dis. Public Health 7, 47-50.

Jones, I.G., Roworth, M., 1996. An outbreak of Escherichia coli 0157 and campylobacteriosis associated with contamination of a drinking water supply. Public Health $110,277-282$.

Olsen, S.J., Miller, G., Breuer, T., Kennedy, M., Higgins, C., Walford, J., McKee, G., Fox, K., Bibb, W., Mead, P., 2002. A waterborne outbreak of Escherichia coli 0157:H7 infections and hemolytic uremic syndrome: implications for rural water systems. Emerg. Infect. Dis. 8, 370-375.

Paunio, M., Pebody, R., Keskimäki, M., Kokki, M., Ruutu, P., Oinonen, S., Vuotari, V., Siitonen, A., Lahti, E., Leinikki, P., 1999. Swimming-associated outbreak of Escherichia coli 0157:H7. Epidemiol. Infect. 122, 1-5.

Scheutz, F., Moller Nielsen, E., Frimodt-Moller, J., Boisen, N., Morabito, S., Tozzoli, R., Nataro, J., Caprioli, A., 2011. Characteristics of the enteroaggregative Shiga toxin/verotoxin-producing Escherichia coli O104:H4 strain causing the outbreak of haemolytic uraemic syndrome in Germany, May to June 2011. Euro Surveill. June 16;16 (24).

Wang, H., Jing, H.Q., Li, H.W., Ni, D.X., Zhao, G.F., Gu, L., Yang, J.C., Shi, Z.Y., Liu, G.Z., Hu, X.S., Xu, J.G., (in Chinese) 2004. Epidemiological study on an outbreak caused by E. coli O157:H7 in Jiangsu province. Zhonghua Liu Xing Bing Xue Za Zhi 25, 938-940.

WHO (World Health Organization), 2011. Small-Scale Water Supplies in the PanEuropean Region - Background - Challenges - Improvements. WHO Regional Office for Europe Scherfigsvej 8, DK-2100, Copenhagen, Denmark. 